\title{
DIVERSITY OF SEGETAL WEEDS IN PEA (Pisum sativum L.) DEPENDING ON CROPS CHOSEN FOR A CROP ROTATION SYSTEM
}

\author{
Marta K. Kostrzewska, Magdalena Jastrzębska, Kinga Treder, Maria Wanic \\ University of Warmia and Mazury in Olsztyn \\ Department of Agricultural Systems, Pl. Łódzki 3, 10-718 Olsztyn \\ e-mail: marta.kostrzewska@uwm.edu.pl; jama@uwm.edu.pl; kinga.treder@uwm.edu.pl; mwanic@uwm.edu.pl
}

Received: 15.12.2013

\begin{abstract}
This study, lasting from 1999 to 2006, was conducted at the Research Station in Tomaszkowo, which belongs to the University of Warmia and Mazury in Olsztyn. The experiment was set up on brown rusty soil classified as good rye complex 5 in the Polish soil valuation system. The analysis comprised weeds in fields sown with pea cultivated in two four-field crop rotation systems with a different first crop: A. potato - spring barley pea - spring barley; B. mixture of spring barley with pea - spring barley - pea - spring barley. Every year, at the 2-3 true leaf stage of pea, the species composition and density of individual weed species were determined; in addition, before harvesting the main crop, the dry matter of weeds was weighed. The results were used to analyze the constancy of weed taxa, species diversity, and the evenness and dominance indices, to determine the relationships between all biological indicators analyzed and weather conditions, and to calculate the indices of similarity, in terms of species composition, density and biomass of weeds, between the crop rotations compared.

The species richness, density and biomass of weeds in fields with field pea were not differentiated by the choice of the initial crop in a given rotation system. In the spring, the total number of identified taxa was 28 and it increased to 36 before the harvest of pea plants. Chenopodium album and Echinochloa crus-galli were the most numerous. Chenopodium album, Echinochloa crus-galli, Sonchus arvensis, Fallopia convolvulus and Viola arvensis were constant in all treatments, regardless of what the first crop in rotation was or when the observations were made.

The species diversity and the evenness and species dominance indices varied significantly between years and dates of observations. Species diversity calculated on the basis of the density of weed species was higher in the rotation with a mixture of cereals and legumes, while that calculated on the basis of weed biomass was higher in the system with potato. The similarity indices, which express the convergence of floristic composition as well as of the density and biomass of weeds growing in pea fields in the two crop rotation systems compared, were within a broad range $(42-86 \%)$. The biodiversity of weed com-
\end{abstract}

munities was more closely correlated to total precipitation than to air temperature.

Key words: Pisum sativum, weed infestation, Shannon-Wiener diversity and evenness indices, similarity index, precipitation, temperature

\section{INTRODUCTION}

Weeds are an omnipresent component of phytocenoses formed in agricultural ecosystems. The composition of herbal plants, their density and the biomass of the whole community of segetal plants depend on habitat-specific and agronomic factors. The problem is most often investigated with respect to fields of cereals, which are dominant agricultural crops [1-7]. In contrast, there is a paucity of reports on weeds infesting leguminous plants, including pea [8-10].

Loss of yields of leguminous crops due to weeds may range between 5 and 30\%, depending on the degree of infestation [11]. Crop rotation is this element of agronomic practice which does not incur additional costs, protects crop yields and is an eco-friendly way to control weeds $[8,12,13]$. In recent years, the role of potato as a rotation crop has been decreasing, while oilseed rape has gained more importance [14]. There is still little interest in growing leguminous crops, either sown as pure plantations or mixed with cereals, which might become an important element in the field production of high protein feeds.

The purpose of this study was to evaluate the degree of weed infestation of pea grown in crop rotation systems with a different first crop (potato or a mixture of legumes and cereals), taking into account the density and biomass of weeds, indices of dominance and diversity as well as indices of similarity. The analysis 
was expanded by adding the dependencies between the above biological indices and atmospheric conditions (temperature and precipitation).

\section{MATERIALS AND METHODS}

The results are derived from a controlled static field experiment conducted at the Research Station in Tomaszkowo $\left(53^{\circ} 25^{\prime} \mathrm{N}, 20^{\circ} 25^{\prime} \mathrm{E}\right)$, which belongs to the University of Warmia and Mazury in Olsztyn. The experiment was set up on brown rusty soil developed from sandy loam (pglp in the Polish soil texture classification), deposited on loamy sand (ps and plp). The arable horizon of the soil was composed of $14 \%$ of clay particles, $36 \%$ of silt and $50 \%$ of sand. It contained a high percentage of humus (1.20-1.39\%), was rich in phosphorus and potassium but low in magnesium. The soil reaction was slightly acidic. In the Polish soil valuation system, it was classified as good rye complex, valuation class IVb.

The study encompassed assemblages of weeds in a field of pea Pisum sativum L. (a fodder cultivar 'Albatros' until 2000 and afterwards, in 2001-2006, cv. 'Grapis'). Pea was grown in two four-field rotation systems, in which the first crops were different:

A: potato - spring barley - pea - spring barley

B: a mixture of legumes and cereals - spring barley - pea - spring barley.

The field trials were run from 1999 to 2006, with four replicates. The results presented herein originate from two rotations (I - in 1999-2002, II - 2003-2006).

The plants grown in the experiment received mineral fertilizers at the following rates: $\mathrm{N}-20, \mathrm{P}_{2} \mathrm{O}_{5}$ $-50, \mathrm{~K}_{2} \mathrm{O}-100, \mathrm{MgO}-25 \mathrm{~kg} \times \mathrm{ha}^{-1}$. Pea was sown in the $2^{\text {nd }}$ decade of April, at a density of 100 germinating seeds per $1 \mathrm{~m}^{2}$ seeded to a depth of $3 \mathrm{~cm}$, in rows spaced at $10.5 \mathrm{~cm}$. No chemical herbicides were used during the growing season.

The analysis of weed infestation of pea fields was carried out each year, according to the density and species composition of weeds over an area measuring $0.25 \mathrm{~m}^{2}$ in each plot, with two replicates. The observations were performed on two dates; one in spring, after the $2^{\text {nd }}$ decade leaf had formed, and the other one at the end of vegetative growth of pea plants (on that day, additionally, the dry matter of individual weed species was determined).

The results enabled the author to assess the species richness of weeds and constancy of some species in successive years on the Braun-Blanquet scale [15] and to calculate the indices of species diversity and evenness according to $\mathrm{S} h$ a $\mathrm{n} n$ on and $\mathrm{W}$ i e $\mathrm{n}$ e $\mathrm{r}$ $[16,17]$, the Simpson's dominance index [18] and coefficients of similarities between weed communities from the formula by Søre n s e n [19].
With the aid of linear correlation coefficients, the relationships between the density and biomass of weeds as well as biological parameters versus the amounts of rainfall and average ambient temperature during the analyzed period of time were established. Linear trends were determined for the analyzed characteristics of weed communities.

\section{RESULTS}

During the eight years of observations, pea grew under changeable weather conditions (Table 1). In respect of moisture conditions, as assessed according to the criteria proposed by $\mathrm{Kac} \mathrm{z}$ or ow s k a and Przedpełska and modified by Szwejkowski [20], the years 2002, 2003 and 2005 were classified as dry ones, with precipitation below $300 \mathrm{~mm}$ during the plant growing season, the seasons of 2000 and 2001 were considered moderate (the total precipitation of 318.6 and $367.6 \mathrm{~mm}$, respectively), while the seasons of 1999, 2004 and 2006 were found to be wet (the total rainfall from 388.3 to $412.5 \mathrm{~mm}$ ).

The mean temperatures during the growing seasons ranged $13.6-14.8^{\circ} \mathrm{C}$. The monthly distributions of temperatures in particular years varied. Relative to the long-term average, April in 2002, 2003 and 2005 as well as May in 2002 and 2004 were colder.

In the years 1999-2006, 28 taxa of weeds were identified in pea fields in the spring (Table 2). No significant effect of the crop rotation system on the number of segetal plants was determined. The average number of weeds for the eight years of the experiment was 293.6 indiv $\times \mathrm{m}^{-2}$ in the rotation system with potato and 278.4 indiv $\times \mathrm{m}^{-2}$ in the rotation with the legume and cereal mixture. The most numerous were Chenopodium album (112.8 in the rotation with potato and 100.6 indiv $\times \mathrm{m}^{-2}$ with the mixture) and Echinochloa crus-galli (95.3 and 78.4 indiv $\times \mathrm{m}^{-2}$, respectively). Among the other taxa, numerous occurrences of Sonchus arvensis, Capsella bursa-pastoris, Fallopia convolvulus and Viola arvensis were also observed. All these taxa are constant species in pea fields.

During the growing season of pea plants, the species composition and density of weeds changed. Compared to the spring, the species composition of weeds prior to pea harvest was richer (up to 36 taxa), but their numbers decreased in the rotation with potato and rose in the rotation with the legume-cereal mixture (Tab. 3). Despite these changes, the selection of a plant to start a rotation system did not have any significant influence on the extent of weed infestation, either. Chenopodium album and Echinochloa crusgalli continued to dominate as the most numerous species with constant occurrence, followed by Capsella bursa-pastoris, Fallopia convolvulus and Sonchus arvensis; in the rotation with the mixture of legumes and 
cereals, there was another dominant weed species: Avena fatua.

The total biomass of weeds in pea, like their density, did not depend on which plant was chosen to start off the rotation (differences statistically insignificant). The average biomass reached $230.4 \mathrm{~g}$ in the rotation with potato and $289.5 \mathrm{~g} \times \mathrm{m}^{-2}$ in the rotation with the legume-cereal mixture (Table 3 ). The populations of the most numerous weed species also produced the highest phytomass. The highest biomass was produced by Chenopodium album and Echinochloa crus-galli in the rotation with potato (99.4 $\mathrm{g}$ and $47.2 \mathrm{~g} \times \mathrm{m}^{-2}$, respectively) as well as by Chenopodium album and Avena fatua in the rotation with the cereal-legume mixture (107.9 and $45.6 \mathrm{~g} \times \mathrm{m}^{-2}$, respectively). The results presented herein show that the inclusion of the cereal and legume mixture in a four-year rotation system favoured the development of Avena fatua; this fact was evidenced by an over 9-fold increase in the density of the population of this species before pea harvest, accompanied by an over 5 -fold increase in its biomass compared to the values recorded in the rotation system with potato.

During the whole research period (1999-2006), the species richness of the weed community in the early stage of development of pea plants varied, with an increasing tendency (Fig. 1). The inclusion of the cereal and legume mixture in the rotation increased the number of segetal species in the pea field higher than the presence of potato (by 12-20 taxa and by 11-18 taxa, respectively). The results were similar at the end of the growing season.

Starting from 2003, a steady increase in the density of weeds occurred, and weed plants found better conditions for emergence in the rotation with potato (Fig. 2). In the subsequent plant growing seasons, weed infestation of pea fields was weaker, while from the 2004 season, pea grown in the rotation with the cereal-legume mixture was less infested than in the rotation with potato. Over the whole 8-year-long period, both the density and biomass of weeds during pea harvest were generally higher in the rotation with potato, especially in the last year of the second rotation cycle.

The vernal differentiation of weed infestation of pea depending on the rotation variant was measured with the Shannon-Wiener diversity index and it generally tended to be rather small during the whole research (Fig. 3). The said index reached slightly higher values in the rotation with the mixture than with potato. Larger differences in the density of individual weed species occurred before pea harvest. In the first rotation cycle (1999-2002), the indices of species diversity of weeds in pea grown in the rotation with the cereal-legume mixture were significantly higher (except for the year 2000), whereas in the second cycle (2003-2006) they were more closely comparable between analogous treatments of the juxtaposed rotation systems. However, the values of this index continued to be higher for the weed community in the pea field within the rotation system with the mixture rather than with potato. In turn, the biodiversity expressed by the Shannon-Wiener index relative to the dry matter of weeds in the early and late phase of the growing season was quite even. In the other seasons (except for 2004), the values of this index were markedly higher in the rotation with the mixture than with potato.

The Shannon-Wiener evenness index values calculated in the spring based on the density of species in the two rotation systems throughout the research period were similar and only slightly altered in the subsequent growing seasons (Fig. 4). Before pea harvest, the variability of this index calculated from the number and biomass of weeds showed a similar distribution as the values of the Shannon-Wiener diversity index.

The extent to which one or several species of weeds dominated the whole community, in terms of their numbers, was expressed by the Simpson index of dominance, which was variable in the particular plant growing seasons and between their early and final stage. Moreover, the variation in the values of the Simpson index was not unambiguously attributable to the first crop in rotation (Fig. 5). Compared to the legume and cereal mixture, the inclusion of potato in the rotation tended to increase the dominance of weeds, although the difference diminished in later years of the study. The analysis of dominance based on the air dry matter of weeds showed that in the early growing seasons (1999-2000) the Simpson dominance indices for pea fields in the rotation systems compared were similar, but later one of them increased markedly in the rotation with potato. In the $2^{\text {nd }}$ year of the second rotation cycle (2004), the dominance in the observed phytocenoses decreased distinctly, but at the same time, it was stronger for pea fields in the rotation with the cereal and legume mixture.

The extent of weed infestation of pea in rotations with different first crops was characterized by a considerable degree of similarity (usually above $50 \%$ ) in both the composition of species and in the density of weeds and biomass of individual species (Table 4). At the same time, weed infestation highly varied during the whole study. It was noted that in each year of the experiment weed assemblages in pea formed in the spring were more closely similar in terms of the abundance of individual weed taxa than in their species composition (the respective similarity indices were 64.5-84.6\% and 60.0-78.9\%). During the summertime observations, reverse relationships were determined (a higher degree of coincidence of the species composition than density). The two evaluation times - in the spring (the 2-3 true leaf stage) and in the late summer (before pea harvest) - differentiated the values of the similarity indices, but the changes were irregular: in some years, the values of 
the analyzed traits were more convergent in the spring than in the summer, and vice versa. The calculated values of the Sørensen index reveal a weaker analogy in the first year of the experiment, and its continual increase in the subsequent vegetative seasons.

The dependence of the biological indices calculated for weed assemblages on atmospheric conditions was described with the aid of a linear correlation coefficient (Table 5). It was demonstrated that the species richness of the weed communities increased due to more abundant rainfall in June, which simultaneously depressed the air dry matter of weeds. The ShannonWiener indices of diversity and evenness increased, while the Simpson dominance index decreased under the ambient conditions of high soil moisture in April and June. The emergence of weeds was not favoured by a higher temperature in April (significant negative correlations), but in the following months, when the air temperature was higher, the abundance and air dry matter of these phytocenoses also increased.
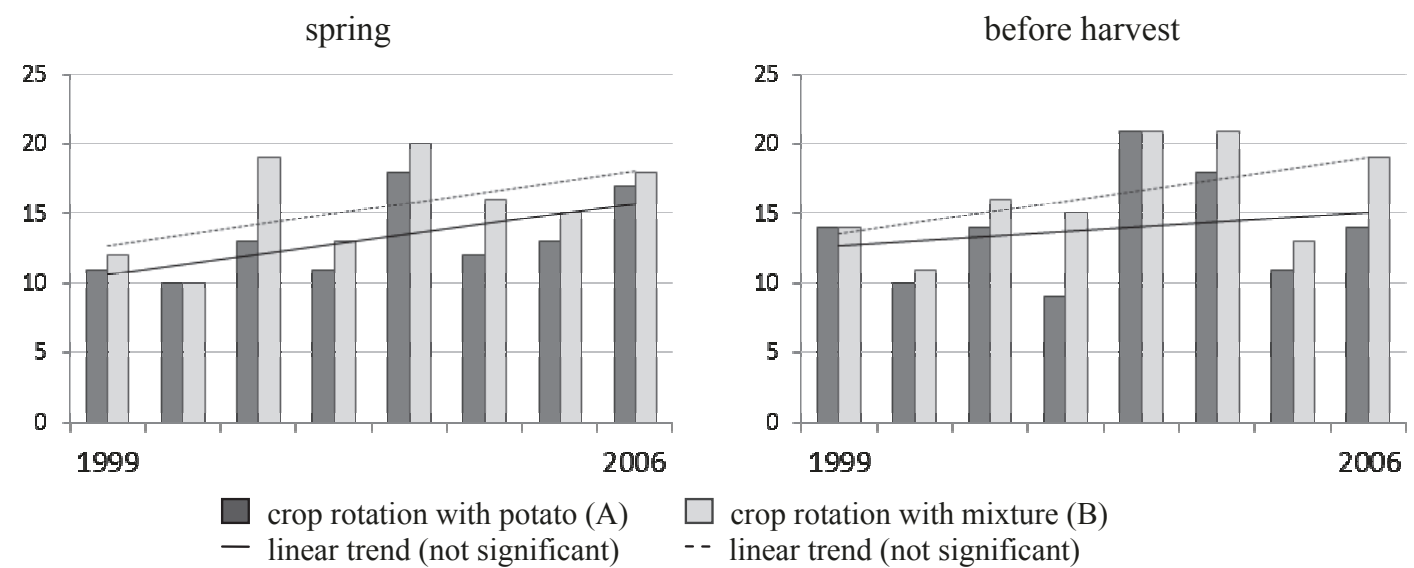

Fig. 1. Species richness of weeds in pea during the whole experiment (1999-2006)

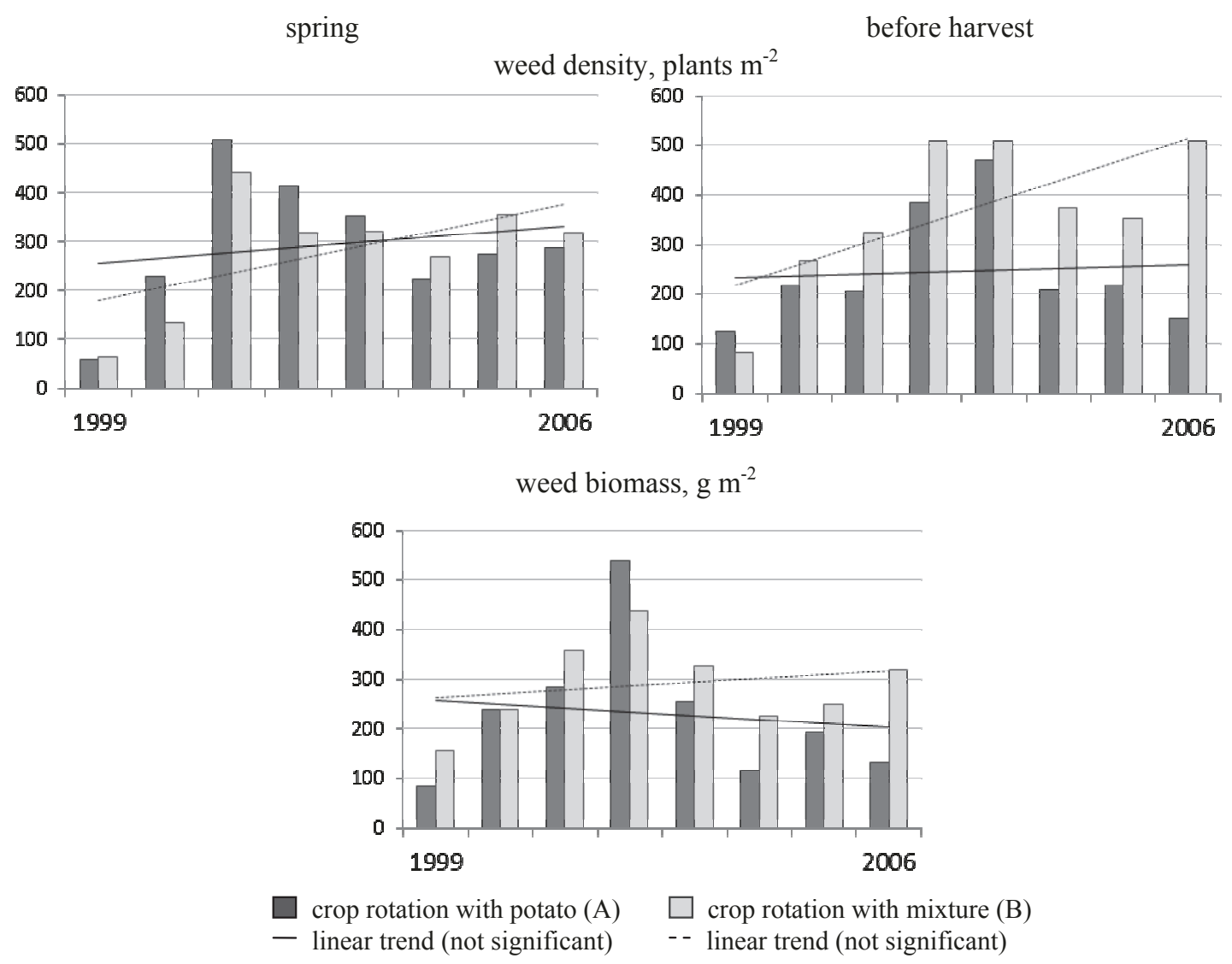

Fig. 2. Density and biomass of weeds in pea during the whole experiment (1999-2006) 


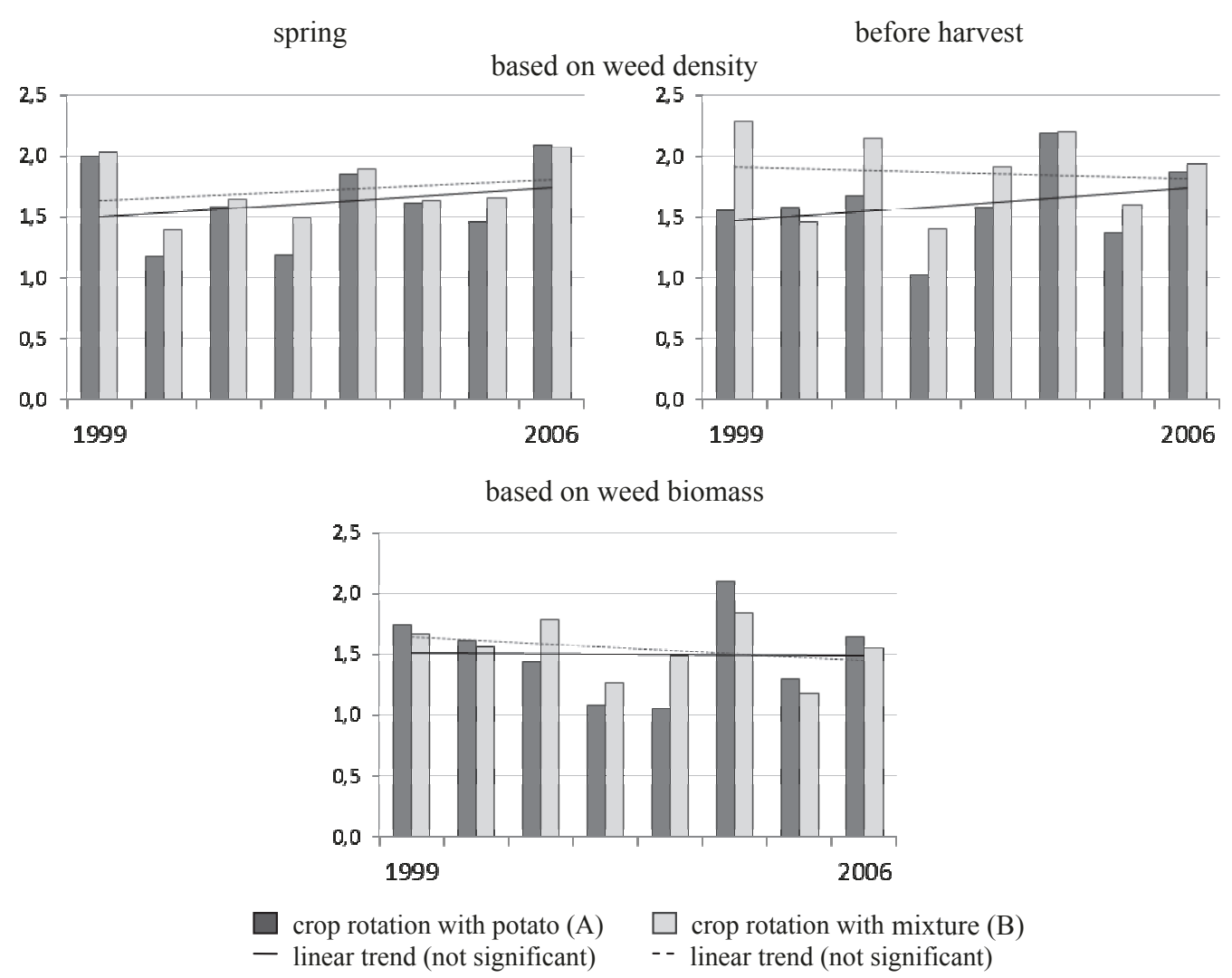

Fig. 3.Shannon-Wiener index of diversity computed on the bases of weed density and biomass during the whole experiment (1999-2006)

spring before harvest

based on weed density
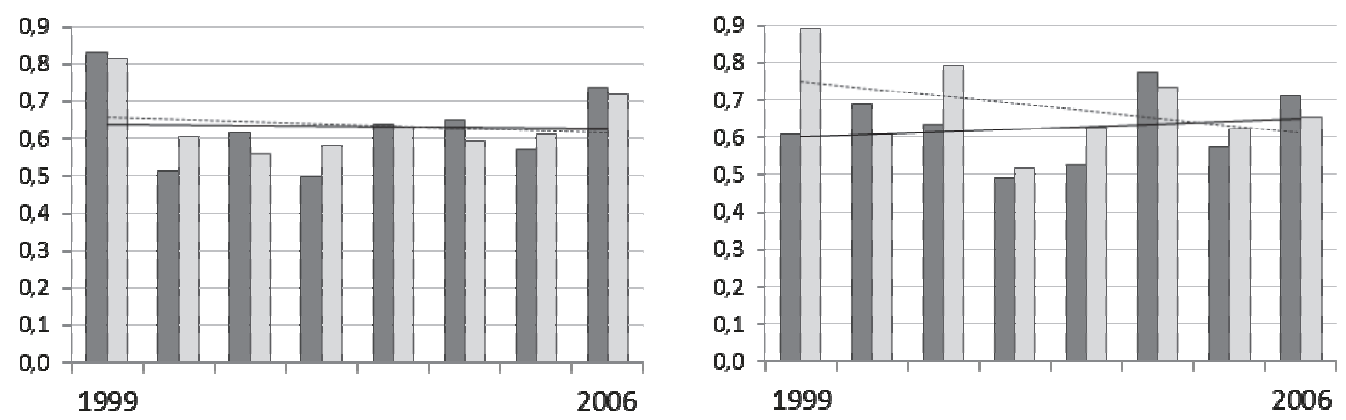

based on weed biomass

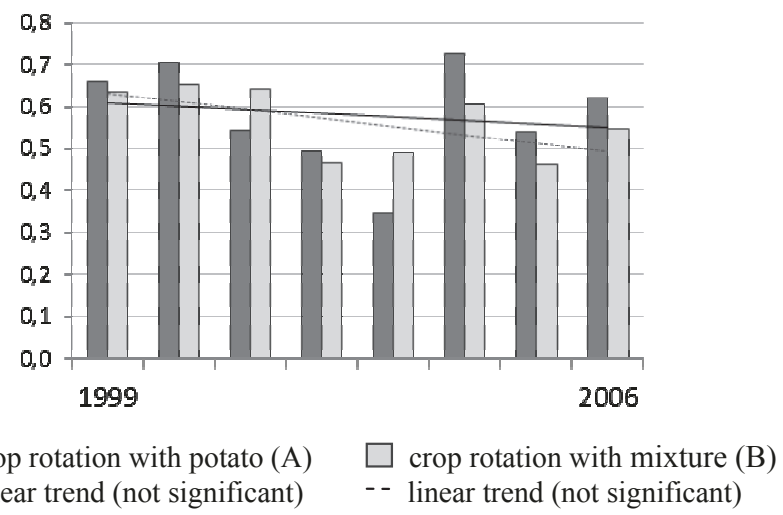

Fig. 4.Shannon-Wiener index of evenness computed on the bases of weed density and biomass during the whole experiment (1999-2006) 
spring

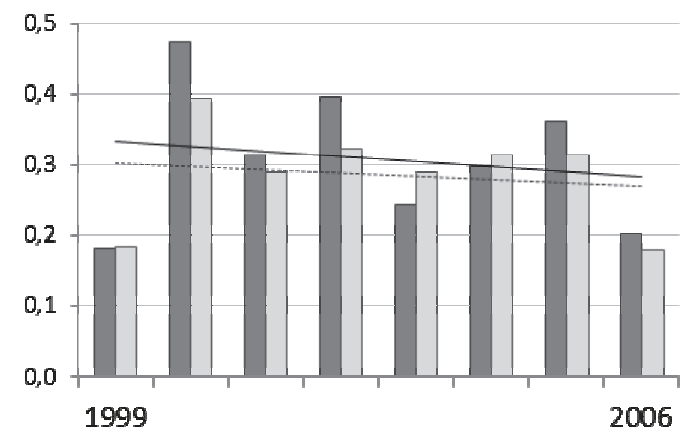

before harvest

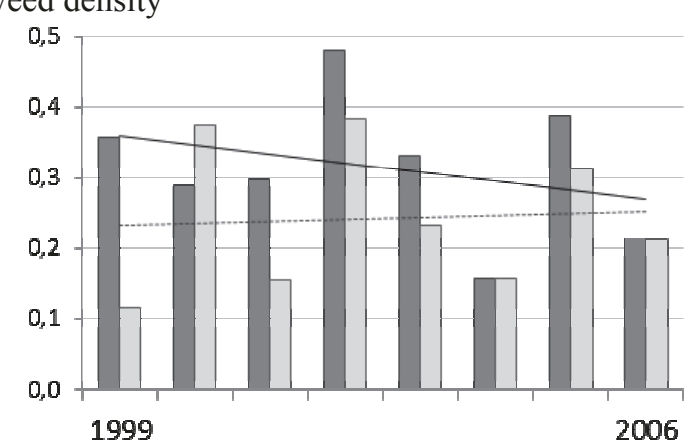

based on weed biomass

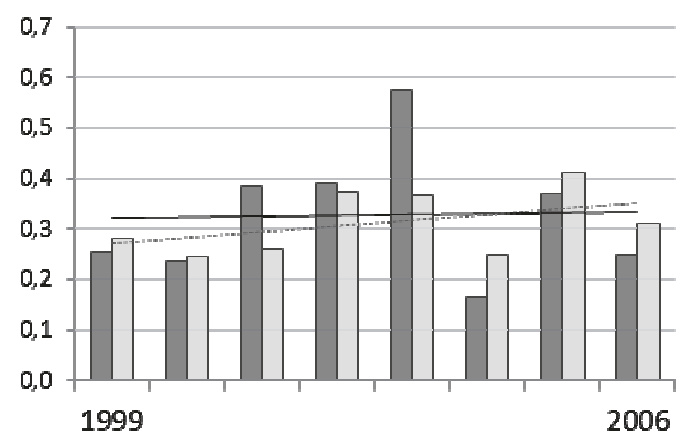

$\square$ crop rotation with potato (A) $\quad \square$ crop rotation with mixture (B)
- linear trend (not significant) $\quad--$ linear trend (not significant)

Fig. 5. Simpson index of dominance computed on the bases of weed density and biomass during the whole experiment (1999-2006)

Table 1

Total precipitation and average daily air temperature during the vegetative growth of pea (from April to August)

\begin{tabular}{|c|c|c|c|c|c|c|c|c|}
\hline \multirow{2}{*}{ Months } & \multicolumn{8}{|c|}{ Years } \\
\hline & 1999 & 2000 & 2001 & 2002 & 2003 & 2004 & 2005 & 2006 \\
\hline \multicolumn{9}{|c|}{ Atmospheric precipitation (mm) } \\
\hline April & 99.3 & 20.8 & 54.9 & 14.2 & 35.5 & 46.5 & 10.9 & 25.6 \\
\hline May & 75.8 & 53.5 & 33.2 & 26.9 & 30.2 & 79.3 & 33.7 & 89.2 \\
\hline June & 113.5 & 34.8 & 77.9 & 48.6 & 72.0 & 111.6 & 47.6 & 79.2 \\
\hline July & 44.3 & 98.7 & 148.6 & 27.5 & 79.2 & 76.1 & 93.6 & 29.3 \\
\hline August & 73.4 & 110.8 & 53.0 & 61.0 & 56.5 & 99.0 & 33.1 & 165.0 \\
\hline Total & 406,3 & 318.6 & 367.6 & 178.2 & 273.4 & 412.5 & 218.9 & 388.3 \\
\hline Classification* & M & $\mathrm{P}$ & $\mathrm{P}$ & BS & $\mathrm{S}$ & $\mathrm{M}$ & $\mathrm{BS}$ & M \\
\hline \multicolumn{9}{|c|}{ Air temperature $\left({ }^{\circ} \mathrm{C}\right)$} \\
\hline April & 8.4 & 10.7 & 7.2 & 4.0 & 6.0 & 7.3 & 6.9 & 7.3 \\
\hline May & 10.9 & 14.0 & 12.8 & 8.1 & 14.1 & 11.0 & 12.5 & 12.5 \\
\hline June & 17.2 & 16.1 & 13.9 & 16.5 & 16.6 & 14.6 & 14.8 & 16.0 \\
\hline July & 19.5 & 15.8 & 20.0 & 20.1 & 19.2 & 16.7 & 18.8 & 20.9 \\
\hline August & 16.9 & 16.9 & 18.1 & 19.8 & 17.4 & 18.2 & 16.2 & 17.2 \\
\hline Average & 14.6 & 14.7 & 14.4 & 13.7 & 14.7 & 13.6 & 13.8 & 14.8 \\
\hline
\end{tabular}

* M - wet, P - average, S - dry, BS - very dry 
Table 2

Density (plants $\mathrm{m}^{-2}$ ) and constancy appearance of weed species in the spring during the 2-3 true leaves phase of pea development (on average for the 8 years)

\begin{tabular}{|c|c|c|c|c|}
\hline \multirow{3}{*}{ Weed species } & \multicolumn{4}{|c|}{ Crop rotation } \\
\hline & \multicolumn{2}{|c|}{ A } & \multicolumn{2}{|c|}{$\mathrm{B}$} \\
\hline & density & constancy & density & constancy \\
\hline Agropyron repens (L.) P. Beauv. & 3.3 & IV & 3.4 & IV \\
\hline Anchusa arvensis (L.) M. Bieb. & 0.4 & II & 0.8 & II \\
\hline Avena fatua $\mathrm{L}$. & 2.0 & II & 8.5 & II \\
\hline Capsella bursa-pastoris (L.) Medik. & 14.0 & IV & 18.0 & $\mathrm{~V}$ \\
\hline Centaurea cyanus $\mathrm{L}$. & 5.3 & $\mathrm{~V}$ & 3.4 & IV \\
\hline Chenopodium album $\mathrm{L}$. & 112.8 & $\mathrm{~V}$ & 100.6 & $\mathrm{~V}$ \\
\hline Cirsium arvense (L.) Scop. & 0.2 & I & & \\
\hline Echinochloa crus-galli (L.) P. Beauv. & 95.3 & $\mathrm{~V}$ & 78.4 & $\mathrm{~V}$ \\
\hline Equisetum arvense $\mathrm{L}$. & 0.9 & II & 0.6 & III \\
\hline Erodium cicutarium (L.) L’Hér. & 0.1 & $\mathrm{I}$ & & \\
\hline Fallopia convolvulus (L.) Á. Löve & 13.5 & $\mathrm{~V}$ & 12.6 & $\mathrm{~V}$ \\
\hline Galeopsis tetrahit $\mathrm{L}$. & 0.1 & $\mathrm{I}$ & 1.6 & IV \\
\hline Galinsoga parviflora Cav. & 2.7 & II & 0.8 & II \\
\hline Galium aparine $\mathrm{L}$. & 1.2 & IV & 0.6 & III \\
\hline Lamium amplexicaule $\mathrm{L}$. & & & 0.2 & II \\
\hline Matricaria maritima L. subsp. inodora (L.) Dostál & 2.0 & III & 1.3 & III \\
\hline Myosotis arvensis (L.) Hill & 0.5 & I & 1.1 & III \\
\hline Polygonum aviculare $\mathrm{L}$. & 0.1 & I & 0.3 & II \\
\hline Polygonum lapathifolium L. subsp. lapathifolium & 0.2 & II & 0.4 & II \\
\hline Raphanus raphanistrum $\mathrm{L}$. & & & 0.6 & II \\
\hline Setaria viridis (L.) P. Beauv. & 0.5 & II & & \\
\hline Sonchus arvensis L. & 16.6 & $\mathrm{~V}$ & 20.5 & $\mathrm{~V}$ \\
\hline Spergula arvensis L. & 3.9 & IV & 9.1 & $\mathrm{~V}$ \\
\hline Stellaria media (L.) Vill. & 0.9 & III & 0.4 & II \\
\hline Thlaspi arvense $\mathrm{L}$. & 2.2 & IV & 2.0 & IV \\
\hline Veronica arvensis L. & 1.4 & II & 1.3 & II \\
\hline Vicia sp. & 3.0 & IV & 3.3 & IV \\
\hline Viola arvensis Murray & 10.5 & $\mathrm{~V}$ & 8.6 & $\mathrm{~V}$ \\
\hline Total & & & & \\
\hline Weed species & & & & \\
\hline
\end{tabular}

A - crop rotation with potato, $\mathrm{B}-$ crop rotation with mixture $\mathrm{a}-$ homogenous groups at $\mathrm{p}=0.05$ 
Tabela 3

Density (plants $\mathrm{m}^{-2}$ ), biomass ( $\mathrm{g}$ ) and constancy appearance of weed species before pea harvest (on average for the 8 years)

\begin{tabular}{|c|c|c|c|c|c|c|}
\hline \multirow{3}{*}{ Weed species } & \multicolumn{6}{|c|}{ Crop rotation } \\
\hline & \multicolumn{3}{|c|}{ A } & \multicolumn{3}{|c|}{$\mathrm{B}$} \\
\hline & density & biomass & constancy & density & biomass & constancy \\
\hline Agropyron repens (L.) P. Beauv. & 4.9 & 3.0 & IV & 20.4 & 11.0 & $\mathrm{~V}$ \\
\hline Anchusa arvensis (L.) M. Bieb. & 0.2 & 0.1 & II & 0.2 & 0.7 & I \\
\hline Apera spica-venti (L.) P. Beauv. & & & & 10.5 & 8.0 & II \\
\hline Avena fatua $\mathrm{L}$. & 4.9 & 8.8 & IV & 43.9 & 45.6 & IV \\
\hline Capsella bursa-pastoris (L.) Medik. & 12.8 & 4.7 & $\mathrm{~V}$ & 18.3 & 5.4 & $\mathrm{~V}$ \\
\hline Centaurea cyanus $\mathrm{L}$. & 5.0 & 15.9 & IV & 7.6 & 20.1 & IV \\
\hline Chamomilla suaveolens (Pursh) Rydb. & 0.4 & $*$ & II & 0.1 & $*$ & I \\
\hline Chenopodium album $\mathrm{L}$. & 91.6 & 99.4 & $\mathrm{~V}$ & 101.4 & 107.9 & $\mathrm{~V}$ \\
\hline Crepis tectorum $\mathrm{L}$. & 0.1 & 0.5 & I & 0.1 & * & III \\
\hline Echinochloa crus-galli (L.) P. Beauv. & 77.3 & 47.2 & $\mathrm{~V}$ & 93.8 & 37.6 & $\mathrm{~V}$ \\
\hline Equisetum arvense $\mathrm{L}$. & & & & 0.2 & 0.1 & I \\
\hline Erodium cicutarium (L.) L’Hér. & & & & 0.1 & * & I \\
\hline Fallopia convolvulus (L.) Á. Löve & 16.9 & 11.0 & $\mathrm{~V}$ & 17.9 & 10.2 & $\mathrm{~V}$ \\
\hline Galeopsis tetrahit $\mathrm{L}$ & 0.1 & 0.5 & I & 0.8 & 1.8 & III \\
\hline Galinsoga parviflora Cav. & 3.0 & 1.4 & IV & 1.0 & 0.2 & IV \\
\hline Galium aparine $\mathrm{L}$. & 0.6 & 0.3 & IV & 0.4 & 0.1 & II \\
\hline Juncus bufonius L. & 0.2 & * & I & & & \\
\hline Matricaria maritima L. subsp. inodora (L.) Dostál & 0.9 & 1.3 & III & 0.9 & 0.8 & II \\
\hline Myosotis arvensis (L.) Hill & 1.4 & 0.3 & III & 2.9 & 3.1 & $\mathrm{~V}$ \\
\hline Papaver rhoeas $\mathrm{L}$. & & & & 0.1 & 0.1 & I \\
\hline Poa annua L. & 0.2 & * & I & & & \\
\hline Polygonum aviculare L. & & & & 0.1 & $*$ & I \\
\hline Polygonum lapathifolium L. subsp. lapathifolium & 0.4 & 0.2 & II & 0.6 & 0.3 & II \\
\hline Raphanus raphanistrum $\mathrm{L}$. & 0.1 & 0.8 & I & 0.1 & $*$ & I \\
\hline Setaria pumila (Poir.) Roem.\& Schult & & & & 0.1 & $*$ & I \\
\hline Setaria viridis (L.) P. Beauv. & 0.2 & $*$ & I & 6.9 & 1.0 & III \\
\hline Silene dichotoma Ehrh. & & & & 0.1 & $*$ & I \\
\hline Sinapis arvensis $\mathrm{L}$. & 0.6 & 2.8 & I & & & \\
\hline Sonchus arvensis L. & 12.4 & 27.0 & $\mathrm{~V}$ & 16.5 & 25.4 & $\mathrm{~V}$ \\
\hline Spergula arvensis L. & 2.5 & 0.8 & III & 5.1 & 3.8 & IV \\
\hline Stellaria media (L.) Vill. & $\mathrm{x}$ & 0.3 & III & $\mathrm{x}$ & 1.4 & II \\
\hline Thlaspi arvense L. & 0.2 & $*$ & I & 1.4 & 0.1 & II \\
\hline Veronica arvensis $\mathrm{L}$. & 1.8 & 0.1 & II & 1.5 & $*$ & II \\
\hline Veronica persica Poir. & 0.4 & $*$ & I & 1.1 & 0.1 & IV \\
\hline Vicia sp. & 2.3 & 2.5 & II & 3.5 & 3.5 & III \\
\hline Viola arvensis Murray & 6.5 & 1.5 & $\mathrm{~V}$ & 8.6 & 1.2 & $\mathrm{~V}$ \\
\hline Total & $247.9 \mathrm{a}$ & $230.4 \mathrm{z}$ & - & $366.2 \mathrm{a}$ & $289.5 z$ & - \\
\hline Weed species & & 29 & & & 33 & \\
\hline
\end{tabular}

$\mathrm{A}-$ crop rotation with potato, $\mathrm{B}-$ crop rotation with mixture

$\mathrm{a}, \mathrm{z}$ - homogenous groups at $\mathrm{p}=0.05$ ( $\mathrm{a}-$ for density, $\mathrm{z}-$ for biomass)

$\mathrm{x}$ - not counted

* - biomass below $0.1 \mathrm{~g}$ 
Table 4

Matrix of similarity indices of weed assemblages between treatments with A and B rotation systems, \%

\begin{tabular}{|c|c|c|c|c|c|c|c|c|}
\hline \multirow{2}{*}{ Time of analyses } & \multicolumn{8}{|c|}{ Years } \\
\hline & 1999 & 2000 & 2001 & 2002 & 2003 & 2004 & 2005 & 2006 \\
\hline \multicolumn{9}{|c|}{ according to species appearance } \\
\hline spring & 69.6 & 60.0 & 81.3 & 75.0 & 78.9 & 64.3 & 71.4 & 74.3 \\
\hline before harvest & 78.6 & 85.7 & 73.3 & 58.3 & 71.4 & 82.1 & 75.0 & 72.7 \\
\hline \multicolumn{9}{|c|}{ according to species density } \\
\hline spring & 64.5 & 64.5 & 83.1 & 78.6 & 78.2 & 84.6 & 80.0 & 78.2 \\
\hline before harvest & 56.7 & 73.5 & 67.5 & 82.6 & 83.5 & 67.7 & 74.6 & 44.7 \\
\hline \multicolumn{9}{|c|}{ according to biomass } \\
\hline before harvest & 41.9 & 82.9 & 76.2 & 82.9 & 83.4 & 83.4 & 74.3 & 44.7 \\
\hline
\end{tabular}

Table 5

Linear correlation coefficients between biological indices and precipitation or temperature during the experiment

\begin{tabular}{|c|c|c|c|c|c|c|c|c|c|}
\hline \multirow{4}{*}{ Item } & \multirow{4}{*}{$\begin{array}{c}\text { Weed } \\
\text { species } \\
\text { richness }\end{array}$} & \multirow{4}{*}{$\begin{array}{l}\text { Weed } \\
\text { density }\end{array}$} & \multirow{4}{*}{$\begin{array}{l}\text { Weed } \\
\text { biomass }\end{array}$} & \multicolumn{6}{|c|}{ Indices } \\
\hline & & & & \multicolumn{4}{|c|}{ Shannon-Wiener } & \multirow{2}{*}{\multicolumn{2}{|c|}{$\begin{array}{c}\text { Simpson of dominance } \\
\text { based on }\end{array}$}} \\
\hline & & & & \multicolumn{2}{|c|}{ diversity based on } & \multicolumn{2}{|c|}{ evenness based on } & & \\
\hline & & & & density & biomass & density & biomass & density & biomass \\
\hline \multicolumn{10}{|c|}{ spring } \\
\hline \multicolumn{10}{|l|}{ April } \\
\hline - precipitations & -0.08 & -0.46 & -0.48 & $0.51 *$ & - & $0.70 *$ & - & $-0.58 *$ & - \\
\hline - air temperature & -0.35 & $-0.55^{*}$ & $-0.61 *$ & -0.01 & - & 0.22 & - & 0.13 & - \\
\hline \multicolumn{10}{|l|}{ May } \\
\hline - precipitations & -0.66 & 0.02 & $-0.63 *$ & 0.58 & - & 0.69 & - & -0.50 & - \\
\hline - air temperature & 0.01 & 0.44 & -0.36 & 0.21 & - & 0.05 & - & -0.01 & - \\
\hline \multicolumn{10}{|c|}{ before harvest } \\
\hline \multicolumn{10}{|l|}{ June } \\
\hline - precipitations & $0.55^{*}$ & -0.31 & $-0.51 *$ & $0.72 *$ & $0.64 *$ & $0.59 *$ & 0.32 & $-0.66^{*}$ & -0.34 \\
\hline - air temperature & -0.06 & 0.06 & 0.01 & -0.26 & -0.24 & -0.23 & -0.16 & 0.26 & 0.15 \\
\hline \multicolumn{10}{|l|}{ July } \\
\hline - precipitations & -0.02 & -0.13 & 0.05 & 0.15 & 0.00 & 0.18 & 0.12 & -0.14 & 0.02 \\
\hline - air temperature & 0.09 & 0.19 & 0.31 & -0.07 & -0.36 & -0.16 & -0.45 & 0.05 & 0.39 \\
\hline \multicolumn{10}{|l|}{ August } \\
\hline - precipitations & 0.11 & -0.08 & 0.25 & 0.29 & 0.44 & 0.28 & 0.44 & -0.34 & $-0.53 *$ \\
\hline - air temperature & 0.07 & 0.39 & $0.68 *$ & -0.18 & -0.09 & -0.26 & -0.17 & 0.18 & 0.06 \\
\hline
\end{tabular}

*- correlation significant at $\mathrm{p}=0.05$

\section{DISCUSSION}

The results presented in this paper confirm some previous reports on strong pressure of weeds in pea fields [8], which is due to the initially slow growth of this leguminous plant. This study also proved that the density of weeds in the said phytocenoses did not change much in response to a different first crop in a rotation system. The literature draws attention to the fact that proper rotation as well as other elements of agronomic practice can control weeds. S obkowicz and Podgórska-Lesiak [21] as well as Buraczyńska [22] showed that the infestation rate of pea grown after oat falls below 50 indiv. $\mathrm{m}^{-2}$. In contrast, weed infestation can become extremely severe if pea is grown after pea for many years [8]. 
According to M ałe ck a et al. [10], traditional and reduced soil tillage destroy emerging weeds and create favourable conditions for seed germination; when tillage is eliminated by direct sowing and herbicides are applied, the abundance and biomass of weeds growing in pea fields can be reduced even more effectively. The high success rate of herbicides applied to pea plantations has been verified by other researchers as well $[8,23]$. According to $\mathrm{S} \mathrm{z}$ w e j k o w s k a [9], the actual weed infestation of pea depends on the level of inputs dedicated to pea cultivation - the higher the inputs, the lower the infestation rate.

Chenopodium album and Echinochloa crusgalli were the species that stood out in terms of their density and biomass, regardless the choice of plants grown in a rotation system. These taxa also dominate in arable fields in Poland [11]. Numerous populations of Sonchus arvensis, Capsella bursa-pastoris and Fallopia convolvulus were also observed. According to R y c h c ik [8], a field of pea sown after spring barley in a six-field rotation system, apart from the aforementioned species, will also be affected by an abundant occurrence of Thlaspi arvense, Viola arvensis and Stellaria media, while the frequently occurring perennial species will include Elymus (Agropyron) repens. K siężak [23] points to Centaurea cyanus, Chenopodium album, Matricaria maritima ssp. indora, Anthemis arvensis and Echinochloa crus-galli as frequent and numerous weed species, whereas $\mathrm{Sz}$ z e jk ow ska [9] considers Galium aparine, Stellaria media, Cirsium arvense, Matricaria chamomilla and Polygonum persicaria as the most noxious taxa.

The analysis of weed infestation based on the indices of diversity, evenness and dominance did not reveal any unidirectional influence of the choice of a crop to start off a rotation cycle on the differentiation of a community of weeds. There seems to be a paucity of reports discussing this issue with reference to pea fields. Most papers deal with experiments based on cereal plants [2,3,24-27]. Likewise, there are very few reports on the biodiversity of fields sown with other fabaceous plants. Jastrzębska et al. [28] discovered weaker species dominance in a bean field than in wheat; also, they concluded that the choice of a crop (winter wheat, spring barley, field bean) had no effect on the diversity and evenness of species in the analyzed weed assemblages, as expressed by the Shannon-Wiener indices. The cited authors point to the high variation of the analyzed traits between years, a finding that was also confirmed by the present study. The factor which differentiates agricultural phytocenoses was the weather in particular plant growing seasons $[9,28]$. In our experiment, too, the type and degree of weed infestation were found to be related to the amount of precipitation and temperature.

\section{CONCLUSIONS}

1. Potato and a mixture of cereal and leguminous plants as crops which start the rotation did not differentiate the species richness, density and biomass of weeds in pea grown for seeds in a four-field rotation system.

2. The most important dominant species in terms of the density and dry matter, irrespective of the time of analysis or crops in rotation, were Chenopodium album and Echinochloa crus-galli.

3. The indices defining species diversity, evenness and dominance showed large variation between years and times of observation. The species diversity was higher in the rotation with the cereal and legume mixture when determined according to the density of species, but when expressed by the biomass produced by weeds, it proved superior in the rotation with potato.

4. During the eight-year study period, the similarity indices calculated from the plant composition in the rotations compared and the density and dry matter of weeds showed high divergence.

5. The species richness and biomass of weeds were modified by meteorological conditions.

\section{Acknowledgments}

The present research was funded by Poland's Ministry of Science and Higher Education as part of the statutory activities of the Department of Agricultural Systems, University of Warmia and Mazury in Olsztyn.

\section{Authors' contributions}

The following declarations about authors' contributions to the research have been made: designing the experiments: MW; field research: MKK, MJ, MW; data analyses: MKK, MJ, KT; comments on the manuscript: MJ; writing the manuscript: MKK, KT.

\section{REFERENCES}

1. Bilalis D, Efthimiadis P, Sidiras N. Effect of three tillage systems on weed flora in a 3-year rotation with four crops. J Agron Crop Sci. 2001; 186(2): 135-141. http:// dx.doi.org/10.1046/j.1439-037X.2001.00458.x

2. Stupnicka-Rodzynkiewicz E, Stępnik K, Lepiarczyk A. Wpływ zmianowania sposobu uprawy roli i herbicydów na bioróżnorodność zbiorowisk chwastów [Effect of the crop rotation, tillage method and herbicides on the biodiversity of weed communities]. Acta Sci Pol Agric. $2004 ; 3(2)$ : 235-245.

3. Wanic M, Jastrzębska M, Kostrzewska MK, Nowicki J. Analysis of weeds communities using selected biological indicators. Acta Agrobot. 2005; 58(1): 227-242. http://dx.doi.org/10.5586/aa.2005.026 
4. Blecharczyk A, Małecka I, Zawada D, Sawinska Z. Bioróżnorodność chwastów w pszenicy ozimej w zależności od wieloletniego nawożenia i systemu następstwa roślin [Weed biodiversity in winter wheat depending on long-term fertilization and cropping systems]. Fragm Agron. 2007; 3(95): 27-33.

5. Skrzyczyńska J, Rzymowska Z, Pawlonka Z. Wpływ systemu gospodarowania na agrofitocenozy Wysoczyzny Siedleckiej [Effect of farming system on agrophytocoenoses in the Siedlce Upland]. Fragm Agron. 2007; 4(96): 176-183.

6. Wojciechowski W, Zawieja J. Oddziaływanie płodozmianów specjalistycznych na dynamikę zachwaszczenia pól [The influence of specialized crop rotations on weed infestation]. Pam Puł. 2007; 145: 255-261.

7. Affek-Starczewska A, Skrzyczyńska J, Skrajna T. Chwasty w uprawach na paszę mieszanek zbóż jarych na glebach lekkich północnej części Wysoczyzny Siedleckiej [The weeds in tillages on fodder of the spring crop's mixtures on light soils of Northern Part Siedlecka Upland]. Fragm Agron. 2008; 3(99): 9-17.

8. Rychcik B. Wpływ następstwa roślin i herbicydu na zachwaszczenie grochu siewnego [Effect of crop sequence and herbicide on weed infestation of pea]. Fragm Agron. 2005; 2(86): 190-196.

9. Szwejkowska B. Reakcja odmian grochu siewnego (Pisum sativum L.) na różne metody zwalczania chwastów [Reaction of pea (Pisum sativum L.) cultivars to different weed control methods]. Acta Sci Pol Agric. 2006; 5(1): 71-82.

10. Małecka I, Blecharczyk A, Dobrzeniecki T. Produkcyjne i środowiskowe skutki wieloletniego stosowania systemów bezorkowych w uprawie grochu siewnego [The productivity and environmental consequences of longterm ploughless tillage systems in field pea]. Fragm Agron. 2009; 26(3): 118-127.

11. Rola J, Rola H. Problemy zwalczania chwastów we współczesnym rolnictwie [Problems of weed control in modern agriculture]. Zesz Nauk AR Wroc Rol. 1996; LXVI: $153-163$.

12. Zaw iśla k K. Regulacyjna funkcja płodozmianu wobec chwastów w agrofitocenozach zbóż [The regulatory role of crop rotations in weed control in cereal agrofitocenoses]. Acta Acad Agric Tech Olst Agric. 1997; 64: 81-99.

13. Jastrzębska M, Bogucka B, Hruszka M. Następstwo roślin i proekologiczne sposoby regulacji zachwaszczenia a bioróżnorodność chwastów w bobiku [Crop sequence and environment-friendly control methods versus weed biodiversity in faba bean fields]. Acta Agroph. 2007; 10(2): 357-371.

14. Rocznik statystyczny rolnictwa [Statistical yearbook of agriculture]. Warsaw: GUS; 2012.

15. Braun-Blanquet I. Pflanzensoziologie. Grundzuge der Vegetationskunde. Vienna: Springer Verlag; 1964.

16. Sh a n n on CE. A mathematical theory of communication. Bell Syst Tech J. 1948; 27(4): 379-423. http://dx.doi.org/ 10.1002/j.1538-7305.1948.tb00917.x
17. Wiener N. Cybernetics, or control and communication in the animal and the machine. Cambridge: The MIT Press; 1948.

18. S i m p s on EH. Measurement of diversity. Nature. 1949; 163(4148): 688-688. http://dx.doi.org/10.1038/163688a0

19. Sørensen T. A method of establishing groups of equal amplitude in plant sociology based on similarity of species and its application to analyses of the vegetation on Danish commons. Biol Skr. 1948; 5: 1-34.

20. Szwejkowski Z. Badania ważniejszych elementów agroklimatu i ich wpływ na plonowanie wybranych roślin uprawnych. Olsztyn: Zakład Agrometeorologii ART w Olsztynie; 1997.

21. Sobkowicz P, Podgórska-Lesiak M. Zmiany w zachwaszczeniu zasiewów czystych i mieszanek dwóch odmian grochu z jęczmieniem pod wpływem nawożenia azotowego [Changes in weed infestation in pure stands and mixtures of two pea cultivars with barley affected by nitrogen fertilization]. Prog Plant Prot Post Ochr Roślin. 2007; 47(3): 271-275.

22. Buraczyńska D. Zachwaszczenie mieszanek strączkowo-zbożowych przy zróżnicowanym składzie ilościowojakościowym [Weed infestation of legume-cereal mixtures associated with different quantitative and qualitative composition]. Prog Plant Prot Post Ochr Roślin. 2009; 49(2): 779-783.

23. Księżak J. Wpływ wybranych herbicydów na rozwój i plonowanie wąskolistnej odmiany grochu siewnego [Influence of selected herbicides on development and yielding of semileafless variety of pea]. Prog Plant Prot Post Ochr Roślin. 2007; 47(3): 169-172.

24. Jędruszczak M, Antoszek R. Sposoby uprawy roli a bioróżnorodność zbiorowisk chwastów w monokulturze pszenicy ozimej [Tillage systems and biodiversity of weed communities in winter wheat monoculture]. Acta Sci Pol Agric. 2004; 3(2): 47-59.

25. Poggio SL. Structure of weed communities occurring in monoculture and intercropping of field pea and barley. Agric Ecosyst Env. 2005; 109(1-2): 48-58. http://dx.doi. org/10.1016/j.agee.2005.02.019

26. Ż u k-G oł a s z e w s k a K. Produkcyjnośćiproduktywność jęczmienia jarego (Hordeum vulgare L.) uprawianego w różnych warunkach agrotechniki [Productivity and productiveness of spring barley (Hordeum vulgare L.) cultivated in different agrotechnical conditions]. Olsztyn: Wyd. UWM; 2008.

27. Kostrzewska MK, Wanic M, Jastrzębska M. Weed infestation of a cereal-legume mixture depending on its concentration and position in a crop rotation. Acta Agrobot. 2012; 65(3): 99-108. http://dx.doi.org/10.5586/ aa.2012.013

28. Jastrzębska M, Orzech K, Kostrzewska MK, Wanic M, Nowicki J. Różnorodność chwastów w łanach roślin przy różnych sposobach uprawy roli [Weed diversity in the plant canopies with different methods of soil cultivation]. Fragm Agron. 2006; 4(92): 103-118. 


\section{Różnorodność chwastów segetalnych w grochu siewnym (Pisum sativum L.) w zależności od doboru roślin w płodozmianie}

\section{Streszczenie}

Badania przeprowadzono w latach 1999-2006 na obiektach statycznego doświadczenia polowego założonego w Stacji Dydaktyczno-Doświadczalnej w Tomaszkowie należącej do UWM w Olsztynie. Eksperyment zlokalizowano na glebie brunatno-rdzawej, kompleksu 5-żytniego dobrego. Przedmiotem badań były chwasty w grochu siewnym uprawianym w dwóch 4-polowych płodozmianach różniących się rośliną rozpoczynającą rotację: A) ziemniak - jęczmień jary - groch siewny - jęczmień jary; B) mieszanka jęczmienia jarego z grochem siewnym - jęczmień jary - groch siewny jęczmień jary. Corocznie, w fazie 2-3 liści właściwych grochu określano skład gatunkowy i zagęszczenie poszczególnych gatunków chwastów, a przed zbiorem rośliny uprawnej - dodatkowo ich suchą masę. Otrzymane wyniki posłużyły do przeprowadzenia analizy stałości pojawiania się poszczególnych taksonów, wyliczenia wskaźników różnorodności, równomierności i dominacji gatunkowej, określenia zależności między badanymi wskaźnikami biologicznymi a układem wa- runków pogodowych oraz wyliczenia współczynników podobieństwa według składu gatunkowego, zagęszczenia i biomasy chwastów między porównywanymi płodozmianami.

Bogactwo gatunkowe, zagęszczenie i biomasa chwastów w grochu siewnym nie były różnicowane doborem rośliny rozpoczynającej płodozmian. Wiosną zidentyfikowano łącznie 28 taksonów, a przed zbiorem grochu - 36 taksonów chwastów. Najliczniej występowały Chenopodium album i Echinochloa crus-galli. Gatunkami stałymi, niezależnie od terminu badań i doboru rośliny rozpoczynającej płodozmian, były: Chenopodium album, Echinochloa crus-galli, Sonchus arvensis, Fallopia convolvulus i Viola arvensis. Wskaźniki różnorodności, równomierności i dominacji gatunkowej wykazywały duże zróżnicowanie w latach i terminach badań. Różnorodność gatunkowa określona na podstawie zagęszczenia gatunków chwastów była większa w rotacji z mieszanką zbożowo-strączkową, zaś mierzona biomasą - w płodozmianie z ziemniakiem. Współczynniki podobieństwa wyrażające zbieżność składu florystycznego, zagęszczenia i biomasy chwastów w grochu uprawianym w porównywanych płodozmianach zawierały się w szerokim przedziale (42-86\%). Wykazano silniejszy związek bioróżnorodności zbiorowisk chwastów z ilością opadów niż temperaturą.

Handling Editor: Elżbieta Weryszko-Chmielewska

This is an Open Access digital version of the article distributed under the terms of the Creative Commons Attribution 3.0 License (creativecommons.org/licenses/by/3.0/), which permits redistribution, commercial and non-commercial, provided that the article is properly cited.

(CThe Author(s) 2014 Published by Polish Botanical Society 